\title{
DeLone and McLean Information Systems Success Model in a Blended-Learning Context
}

Ibrahim Abdalla Alfaki, College of Business and Economics, United Arab Emirates University, UAE

\begin{abstract}
This study evaluates the success of the blended-learning mode in the context of a higher education institution in the Arabian Gulf region, utilizing the updated DeLone and McLean information systems success model. Students were surveyed about their perceptions of and feedback on the different characteristics of blended learning. Use of the blended-learning system and student satisfaction had a significant positive influence on net benefits. The service quality aspects of the blended-learning system - collaboration, support, and interaction between involved parties—-provided strong support to both system use and student satisfaction. This study is one of only a few to evaluate blended learning in the Arabian Gulf region. The findings increase understanding of blended-learning system use in the entire region and shed light on its relation to student contentment. This would aid the curriculum design process, resource allocation, adoption, and customization of the blended-learning modality.
\end{abstract}

\section{KEYWORDS}

D\&M IS Framework, E-Learning, Learning Delivery, Service Quality, Student Satisfaction, System Quality

\section{INTRODUCTION}

Recent advancements in computer and digital technology have led to the development of new models of teaching and learning that differ from traditional instruction. One such model is blended learning, a concept that dates to the advent of digital technology and is intended to individualize the learning process and bridge distance and time through correspondence courses (Bryan \& Volchenkova, 2016). As such, this model offers students partial control over aspects of their learning and is associated with improved pedagogy and increased information access.

The term blended learning is context-dependent and has been defined differently by various scholars (Graham, 2006; Hew \& Cheung, 2014; Krasnova, 2015; Oliver \& Trigwell, 2005; Staker $\&$ Horn, 2012). There is agreement that blended learning is an integrated learning experience controlled and guided by instructors in the form of face-to-face communication or virtual presence. Lalima and Dangwal (2017) defined blended learning as embracing the advantages of both traditional classroom teaching and information and communication technology (ICT)-supported learning, with the potential for collaborative, constructive, and computer-assisted learning. According to Rovai and Jordan (2004), a blended course can lie anywhere between fully face-to-face and fully virtual e-learning (online) modalities.

Higher education institutions in the United Arab Emirates (UAE) have pioneered the integration of digital technology in education in the Gulf and the wider Arab region (Ahmed \& Al Marzouqi, 2015; Alkaabi et al., 2016). Ahmed and Al Marzouqi (2015) found that blended teaching significantly 
enhanced learning and level of understanding among the United Arab Emirates University (UAEU) engineering students. Yet, their findings cannot be generalized because of the limited scope and sample coverage. AlMurshidi (2017) surveyed UAEU College of Education students engaged in a mobile learning project that was to subsequently transition to blended delivery. Students reported several positives, including bridging distance and time and eliminating the need for books. However, they also mentioned several drawbacks, including difficulty accessing the network and device limitations, such as battery life and memory capacity.

This study is driven by a need to assess the level of acceptance and usefulness of blended learning in higher education institutions in the Arabian Gulf Region, focusing on the UAEU. The UAEU is ranked among the top five Arab universities and is number 284 worldwide, according to the 2020 QS ranking system. The university is investing considerable resources to transform classrooms into collaborative, technology-based teaching environments. It is monitoring, through the UAEU Center for Excellence in Teaching \& Learning, a transformation from traditional learning to a blended-learning approach. Several UAEU courses have transitioned to blended learning, yet few investigations have assessed student satisfaction (SS), information quality (IQ), service quality (SERQ), system use (SU), and overall system quality (SQ).

The main objective of this study is to use DeLone and McLean's information system success (D\&M ISS) model and theory to evaluate the success of the blended-learning mode (DeLone \& McLean, 1992, 2003), using UAEU data. To better account for the face-to-face factor of the blended modality, the SQ component of the original D\&M ISS model has been updated to use measures of instruction quality, engagement, and interaction among instructors and peers. This reflects possible influence of the social bond in the success of the system. Originally, SERQ was used to measure the level of ICT support, information content, and delivery.

\section{Literature Review}

Scholars have cited cost reduction as one of the benefits of blended learning. Other advantages include unlimited access to learning materials irrespective of geographic location, increased time efficiency, ease of communication and instructor-student interaction, better adherence to students' needs, and additional support in course content problem-solving (Owston et al., 2013; Szadziewska \& Kujawski, 2017; Wu et al., 2010).

Several drawbacks to blended learning have also been noted. For example, successful implementation of the approach requires efficient network connections, accessibility of electronic devices, a suitable curriculum, and students' ability to use technology and to learn independently. Scholars have related the acceptance of blended learning to factors including gender, age, and cultural background (Alkaabi et al., 2016). Moreover, the lack of immediate response in asynchronous models, compared to the immediate feedback in face-to-face learning, results in a loss of the sense of community and group identity (Vonderwell, 2003). Further, students find it difficult to establish socio-emotional interactions, and instructors need the right ICT support to adapt to the changing nature of technology. Despite these challenges, the adoption of blended learning is increasing, as its benefits greatly exceed its drawbacks.

Sharpe et al. (2006) identified three models of blended learning. In the transmissive pedagogical model, delivery and learning mainly rely on traditional face-to-face lectures and seminars, in which the teacher fully controls knowledge delivery. Students receive extra support via online lecture notes available in the institution's virtual learning environments (VLEs). The transformative model involves extensive use of ICT tools beyond VLEs to enhance and alter students' modes of interaction, studying, and learning. It is underpinned by radical course redesign. Through dynamic interactions, learners are actively involved in constructing knowledge, not just receiving it. This mode of blended learning promotes intellectual activities that are dependent on the use of technology (Graham, 2006). Currently, the transformative model is widely adopted by higher education institutions, developed through a constructive alignment of assessment strategies with learning objectives (Biggs, 2011). The holistic 
model is characterized by situations in which most learners do not distinguish between learning with or without technology. The instructor facilitates learning by using students' own technology devices and platforms, including mobile phones, online communities, and instant messaging.

Bouilheres et al. (2020) surveyed students from business and science and technology schools at an Australian university, examining students' perceptions of blended learning and whether the blended environment increased engagement between students, instructors, and learning materials. The factor analysis results indicated positive student perception of blended learning.

Atmacasoy and Aksu (2018) synthesized research on the implementation of blended learning at teachers' education programs in Turkey and investigated its impact on learners' achievements and attitudes. They concluded that blended learning was more effective than face-to-face learning or purely online learning as it mainly relied on integrating the best of the two approaches. However, they stressed the importance of an appropriate ICT infrastructure and network, as well as reliable communications connectivity.

Yakubu and Dasuki (2018) used the D\&M ISS model to examine factors contributing to the acceptance of the e-learning system in a private university in Nigeria. Their results supported positive relations between the quality of the system, students' intentions to use the system, and students' satisfaction. Similarly, information and SERQ were positively related to students' intentions to use the system and SS, which were in turn positively related to actual SU. No association was found between SERQ and SS, IQ and SS, SERQ and intention to use the system, and SS and intention to use the system. One clear limitation of the investigation was the absence of factors including instructor feedback and student interaction.

Chen and Jones (2007) investigated the perceptions of two groups of MBA students in the same accounting course. One group was engaged in a blended-learning mode and the other in a traditionallearning setting. The authors reported no differences in learning outcomes for the two groups. However, they indicated that the blended-learning group had developed improved analytical skills and better understanding of concepts in the field. Nevertheless, the blended-learning group found the course harder versus the traditional-learning group. Furthermore, the traditional-learning group expressed more satisfaction with the clarity of the instructions. Overall, both methods received positive feedback, and no differences were found in motivation or confidence in the ability to understand and apply the learning concepts.

Alkaabi et al. (2016) highlighted universal and UAE-specific factors that affected achievement in a blended-learning environment. They discussed three factors: academic caring, self-efficacy, and social interaction. Academic caring entails frequent instructor-student interactions and support for student well-being. According to Wentzel (2009), from the student perspective, the willingness of the instructors to be available and to mindfully attend to their academic needs are elements of academic caring. Self-efficacy is the belief in one's capabilities to execute the actions required to produce given attainments (Bandura, 1986). Social interaction refers to the level of online interaction between students, their peers, and course instructors (Alkaabi et al., 2016). According to Alkaabi et al. (2016), several scholars have raised concerns that blended learning is being used as an information source rather than a medium of interaction with content and social interaction.

\section{Background}

The updated DeLone and McLean (2003) model is an information systems (IS) theory that defines IS success by identifying, describing, and explaining the relationships among six of the most critical dimensions of success along which an IS might be evaluated (Figure 1).

Source: DeLone and McLean (2003)

In this context, an IS is defined as a set of coordinated network components that act together to produce, distribute, or process information (Boell \& Cecez-Kecmanovic, 2015). What matters in the IS is the application of technology that meets the needs of the different users and their specific objectives and practices. According to DeLone and McLean (2003), an IS can be evaluated based 


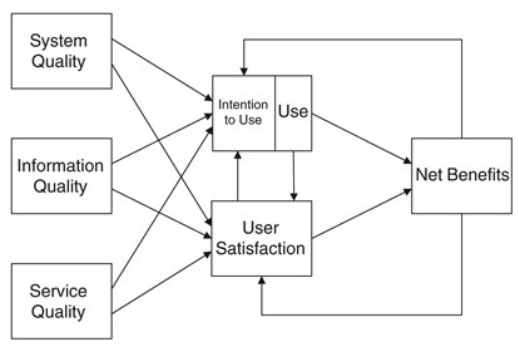

on the information, system, and SERQ it provides. These three qualities directly influence the use or intention to use the system and user satisfaction. The model also postulates that certain benefits can be achieved by using the system. Further, SU, together with user satisfaction, will be influenced positively or negatively by net benefits (NB).

Several scholars have evaluated the e-learning teaching approach using the D\&M ISS model (Lee-Post, 2009; Ramayah et al., 2010; Yakubu \& Dasuki, 2018). In contrast to the blended-learning approach, e-learning occurs entirely online. Thus, to assess the success of the blended-learning modality utilizing the D\&M IS framework, the face-to-face component of the blended-learning mode should be accounted for as an important dimension of success. Such a dimension has a clear manifestation in the SERQ, through instructors, peer contributions, and social interactions.

Thus, within the blended-learning delivery context, the D\&M ISS model offers an understanding of interrelationships between blended-learning quality factors, SU, and user satisfaction when assessing the end user NB. Based on a literature review, Urbach and Müller (2012) produced lists of validated measures that can be used to operationalize success dimensions of the D\&M ISS model. The lists are meant to serve as a starting point in the search for context-driven measures.

\section{System Quality}

The SQ dimension stresses desirable IS characteristics, focusing on measures of usability and performance. Common measures in this dimension are perceived ease of use, system accessibility, accuracy, reliability, and interactivity (Table 1). In the current study, however, SQ is evaluated in the context of a blended-learning delivery system and the additional elements of success needed to measure this dimension. These include reliability, clarity of information, overall performance of the learning management portal used, and the effective use of multimedia to promote interactivity among involved parties (Wu et al., 2010).

\section{Information Quality}

The IQ dimension is concerned with content issues and desirable characteristics of the IS output. It focuses on measures of quality and usefulness of the information produced by the system. Urbach and Müller (2012) noted that IQ is the key criterion for user satisfaction. In their review of measures used to operationalize this construct, they listed several items (Table 1) that are consistent with the IQ needed for blended learning, including information organization, precision, relevancy, and currency.

\section{Service Quality}

The SERQ dimension describes the level of support received by the IS user. This support includes training provision, hotline services, or helpdesk availability. Urbach and Müller (2012) listed possible proxies to the IS SERQ (see Table 1). In the blended delivery context, SERQ implies the existence of a stable ICT system and the efficient utilization of a learning management portal. 
In addition to using instructor support, the current study follows Holsapple and Lee-Post's (2006) suggestion of using student-instructor interaction to assess SERQ. Instructor support has several manifestations, including instructor availability, fairness, and knowledge of blended-learning technology; clear and prompt communication of class activities and tasks; and encouragement of student participation in course activities. Peers can further contribute to the provision of high-quality service by maintaining appropriate on- and offline interactions and feedback that encourage other students to explore and learn.

\section{Intention to Use/Actual Use}

The dimension of intention to use/actual use reflects the degree and manner of utilization of the IS. The Technology Acceptance Model (TAM) (Davis, 1989) offers a comprehensive approach to measure this dimension using variables such as perceived ease of use and perceived usefulness, both of which contribute to attitude toward use, intention to use, and actual use. Urbach and Müller (2012) noted that, due to difðculties in interpreting the use dimension, DeLone and McLean suggested intention to use as an alternative measure for use in some contexts. Table 1 summarizes the variables Urbach and Müller (2012) employed to measure use or intention to use the IS. In this study, however, measures of actual SU were adopted, rather than intention to use.

\section{User Satisfaction}

The user satisfaction dimension is measured when the IS system is utilized. Several authors (e.g., Doll et al., 2004; Ives et al., 1983) have listed measures of user satisfaction. These instruments also include items of SQ, IQ, and SERQ (Table 1). In the online and blended-learning context, researchers have utilized different methods to define and assess student satisfaction, including final grades, students' attitudes toward online classes, and students' self-report of satisfaction (Park \& Choi, 2009; Patterson \& McFadden, 2009).

\section{Net Benefits}

NB are a measure of the contribution of the IS to the success of the different stakeholders. Measures of NB are combined into one dimension, mainly including individual and organizational impacts, together with work group and societal impacts (Table 1). As argued by many researchers, NB constitute a context-driven dimension that largely depends on the specific research problem, purpose of the study, and level of analysis. Despite the association and dependency between NB, measures of user satisfaction, and SU, researchers have alluded to measuring it directly. In financial and market-based studies, investigators have attempted to quantify NB through numerical measures such as profitability, cost, market share, or productivity.

Table 1 highlights measures utilized by researchers to operationalize IS NB on both an individual and organizational basis. This study employs measures that operationalize this dimension in the context of a student's NB from the blended-learning system. Thus, NB can be measured via improvement in learning productivity, tasks accomplishment, and enhanced effectiveness of activities.

\section{Study Hypotheses}

The study intends to use D\&M ISS model and theory to evaluate the success of the blended-learning mode in UAEU. It makes several assumptions regarding the success of the blended-learning system. According to the updated DeLone and McLean (2003) theoretical framework, six dimensions contribute to the success of the blended-learning system (Figure 1). Theoretically, the blendedlearning SQ, IQ, and SERQ are expected to have a positive influence on SS and SU. This, in turn, will influence NB. SU is further assumed to be influenced by SS. The following nine research hypotheses are formulated: 
Table 1.Constructs and Measures of the Updated D\&M ISS Model, Based on Urbach and Müller's (2012) Review

\begin{tabular}{|c|c|c|c|c|c|c|}
\hline \multirow{2}{*}{ System quality } & \multirow{2}{*}{$\begin{array}{c}\text { Information } \\
\text { Quality }\end{array}$} & \multirow{2}{*}{$\begin{array}{l}\text { Service } \\
\text { Quality }\end{array}$} & \multirow{2}{*}{$\begin{array}{c}\text { Intension to Use/ } \\
\text { Use }\end{array}$} & \multirow{2}{*}{ User Satisfaction } & \multicolumn{2}{|c|}{ Net Benefit (Impact) } \\
\hline & & & & & Individual & Organizational \\
\hline Access & Accuracy & Assurance & Actual use & Adequacy & $\begin{array}{l}\text { Awareness/ } \\
\text { Recall }\end{array}$ & $\begin{array}{c}\text { Business process } \\
\text { change }\end{array}$ \\
\hline Convenience & Availability & Empathy & Daily use & Effectiveness & $\begin{array}{l}\text { Decision } \\
\text { effectiveness }\end{array}$ & $\begin{array}{l}\text { Competitive } \\
\text { advantages }\end{array}$ \\
\hline Customization & Conciseness & Flexibility & Frequency of use & Efficiency & $\begin{array}{l}\text { Individual } \\
\text { productivity }\end{array}$ & Cost reduction \\
\hline Data accuracy & Format & $\begin{array}{l}\text { Interpersonal } \\
\text { quality }\end{array}$ & $\begin{array}{c}\text { Intention to (re) } \\
\text { use }\end{array}$ & Enjoyment & Job effectiveness & $\begin{array}{l}\text { Enhancement of } \\
\text { communication and } \\
\text { coordination }\end{array}$ \\
\hline Data currency & Relevance & $\begin{array}{l}\text { Intrinsic } \\
\text { quality }\end{array}$ & Nature of use & $\begin{array}{l}\text { Information } \\
\text { satisfaction }\end{array}$ & Job performance & $\begin{array}{l}\text { Enhancement of } \\
\text { internal operations }\end{array}$ \\
\hline Ease of learning & Reliability & IS training & $\begin{array}{l}\text { Navigation } \\
\text { patterns }\end{array}$ & $\begin{array}{c}\text { Overall } \\
\text { satisfaction }\end{array}$ & Job simplification & $\begin{array}{l}\text { Enhancement of } \\
\text { reputation }\end{array}$ \\
\hline Ease of use & Timelines & Reliability & $\begin{array}{l}\text { Number of site } \\
\text { visits }\end{array}$ & $\begin{array}{c}\text { System } \\
\text { satisfaction }\end{array}$ & Learning & $\begin{array}{c}\text { Improved outcomes/ } \\
\text { outputs }\end{array}$ \\
\hline Efficiency & $\begin{array}{l}\text { Understand- } \\
\text { ability }\end{array}$ & $\begin{array}{l}\text { Responsive- } \\
\text { ness }\end{array}$ & $\begin{array}{l}\text { Number of } \\
\text { transactions }\end{array}$ & & Productivity & $\begin{array}{l}\text { Improved decision } \\
\text { making }\end{array}$ \\
\hline Flexibility & Usability & Tangibles & & & Task performance & Increased capacity \\
\hline Integration & Usefulness & & & & Usefulness & Overall productivity \\
\hline Interactivity & & & & & Task innovation & Overall success \\
\hline Navigation & & & & & & Quality improvement \\
\hline Reliability & & & & & & Customer satisfaction \\
\hline Response time & & & & & & Management control \\
\hline \multicolumn{7}{|l|}{ Sophistication } \\
\hline \multicolumn{7}{|l|}{ System accuracy } \\
\hline \multicolumn{7}{|l|}{ System features } \\
\hline Turnaround time & & & & & & \\
\hline
\end{tabular}

$\mathbf{H}_{\mathbf{1}}$ : SQ will have a positive influence on SS in blended learning.

$\mathbf{H}_{2}$ : SQ will have a positive influence on SU of blended learning.

$\mathbf{H}_{3}$ : IQ will have a positive influence on SS in blended learning.

$\mathbf{H}_{4}$ : IQ will have a positive influence on SU of blended learning.

$\mathbf{H}_{5}$ : SERQ will have a positive influence on SS in blended learning.

$\mathbf{H}_{6}$ : SERQ will have a positive influence on SU of blended learning.

$\mathbf{H}_{7}$ : SS will have a positive influence on the NB of blended learning.

$\mathbf{H}_{\mathbf{8}}$ : SU of blended learning will have a positive influence on the NB of blended learning.

$\mathbf{H}_{\mathbf{9}}$ : SS will have a positive influence on SU of blended learning.

\section{METHODOLOGY}

\section{Participants}

This study covered all undergraduate students enrolled in all six blended courses offered by the UAEU in fall 2020. A total of 191 students completed the blended-learning survey, amounting to slightly over $72 \%$ of the total population of the 262 enrolled students (see Table 2). The 15-minute survey questionnaire was distributed to students on paper on the last day of the course, after the final exam. 
Over three quarters of participants were female, which aligns with the 4:1 enrollment ratio of female to male, as indicated in UAEU student enrollment statistics of 2018/2019. UAE national students are the majority group at the university, representing over $80 \%$ of all enrolled students.

\section{Blended Courses}

Table 2 provides a list of the six blended courses with the students enrolled. All courses belonged to the humanities and social sciences disciplines. Three of the courses were lower 100-level courses, two were intermediate 200-level, and one course was a junior 300-level course. These were populated, respectively, by $45 \%, 35 \%$, and $20 \%$ of the surveyed students. The courses had percentages of online modality that ranged from $25 \%$ to $75 \%$, as per the UAEU Center for Excellence in Teaching \& Learning guidelines.

Table 2. Course Title, Department, and Number of Students by Gender

\begin{tabular}{|c|c|c|c|}
\hline \multirow{2}{*}{ Course title } & \multicolumn{2}{|c|}{ Enrolled Students } & \multirow{2}{*}{ Department } \\
\cline { 2 - 3 } & Female & Male & \multirow{2}{*}{ Curriculum \& Instruction } \\
\hline Educational Technology & 28 & 0 & Private Law \\
\hline Commercial Arbitration Law & 28 & 25 & Mass Communication \\
\hline $\begin{array}{c}\text { Public Relations \& Advertising } \\
\text { Principles }\end{array}$ & 35 & 0 & Sociology \\
\hline Social \& Cultural Change & 56 & 0 & Philosophy \\
\hline Critical Thinking & 9 & 22 & English Literature \\
\hline Arts and Society I & 44 & 18 & 265 \\
\hline Total & 200 & 65 & \\
\hline
\end{tabular}

The delivery of almost all UAEU blended courses, including those listed in Table 2, utilizes the Blackboard management system, which is the university's mandatory platform for the delivery of learning and the integration of information and e-learning resources.

\section{Questionnaire Design}

The questionnaire benefited from the existing research on a validated list of measures used to evaluate the blended-learning approach and validate the D\&M ISS model. Urbach and Müller's (2012) review was the main source of the measures adapted for use in this study. Additional measures of instructor-student interaction and peer interactions among students appear in the work of Wu et al. (2010). Pituch and Lee (2006) and Wu et al. (2010) suggested a direct effect of social interaction on the use of e-learning systems. They added that interactions among students, interactions between faculty and students, and learning collaboration are key to learning process effectiveness. Similar remarks were also given by Bouilheres et al. (2020) and Alkaabi et al. (2016). Poelmans and Wessa (2015) proposed instructor support and peer input as proxies for SERQ.

Students enrolled in blended-learning courses at UAEU were surveyed about the different quality aspects and effectiveness of the blended-learning system and their overall level of satisfaction. The first part of the questionnaire asked about students' basic demographic profile, English reading and writing skills, and ICT literacy needed to access course materials. The second part asked for their opinions on different dimensions and constructs related to blended-learning success. The students rated their agreement with each of the 22 items on a 5-point scale from 1 strongly disagree to 5 strongly agree. A statement that received a score of less than 3 was considered to have a "low" agreement rating as 
it indicated some level of disagreement. A response of 3 was labeled "neutral," while a response of more than 3 was labeled "high."

\section{Results}

As detailed in the previous section, the empirical data in this study were obtained primarily through a self-reported questionnaire. Analysis results were presented in three subsections. In Subsection 1, students' ICT and English language preparedness and skills were investigated. Subsection 2 presents an exploratory quantitative analysis conducted to assess individual dimensions of the D\&M ISS model. In Subsection 3, structural equation modeling (SEM) is used as the main tool to test the study hypotheses developed from the six dimensions discussed in Subsection 2 to evaluate the success of the blended learning mode at UAEU.

\section{Participants' ICT Profile}

Students' performance on some of the UAE university curricular requirements that are necessary to enhance the learning process include preexisting Internet and ICT skills, together with oral and writing skills in English - the main language of instruction in UAEU colleges. Communication in English seemed not to be a problem, as over $90 \%$ of participants had intermediate fluency or above, and only approximately $8 \%$ had elementary skills. Over $90 \%$ of participants indicated above-average level of experience in the use of Internet technologies, social media, and multimedia applications.

The Blackboard educational management system, Internet, social media, and multimedia applications were important tools of communication. Four to six or more communications and interactions per week with instructors during the blended course delivery represent the norm for more than two thirds of the surveyed students. This is compared to over one half of the participants when interactions were with classmates.

\section{Evaluating the Dimensions of Blended-Learning Success}

Table 4 depicts participants' evaluation of several desirable characteristics of SQ and performance. Although all statements intended to measure SQ received an above-average rating, system reliability showed the highest percentage of students who agreed or strongly agreed. Only approximately $9 \%$ of the students expressed concerns about system interactivity and learner interactions.

Table 5 shows the percentages and mean responses intended to summarize different measures and characteristics of IQ of the UAEU blended-learning system. More than $80 \%$ of students highly valued the IQ in terms of information precision, organization, currency, relevancy, and reliability. All evaluations were favorable, with an average score exceeding 4 points.

Table 6 indicates that students gave high ratings to instructors' experience regarding the use of the learning technology and timely feedback on assignments and tests. All other characteristics of SERQ, including adequate communications between instructors and students and among students, also received high ratings $(>80 \%)$.

Table 7 indicates that students were highly satisfied with the blended-learning system. Factors contributing to satisfaction included user-friendly technology and ease of navigation that aided the learning process. This might explain the favorable responses regarding willingness to take another blended-learning course. Approximately $80 \%$ of the students said they would recommend a blended course to friends.

As Table 8 shows, students indicated they used the course online materials frequently. They rated as high the ease of use of the technology utilized in the blended-learning process. Over $85 \%$ of participants reported feeling "satisfied with how they are able to apply what they have learned in the course from both the online and face-to-face parts."

As Table 9 indicates, the blended learning delivery enhanced students' study activities and contributed to improving their productivity and time to accomplish tasks. 
Table 3. Participants' Demographics and ICT Profiles

\begin{tabular}{|c|c|}
\hline Variable & $n(\%)$ \\
\hline \multicolumn{2}{|l|}{ Gender } \\
\hline Male & $43(22.5)$ \\
\hline Female & 145 (75.9) \\
\hline \multicolumn{2}{|l|}{ Nationality } \\
\hline UAE & $162(84.8)$ \\
\hline Non-UAE & $25(13.1)$ \\
\hline \multicolumn{2}{|c|}{ Do you consider yourself fluent in reading in English? } \\
\hline Proficient & $52(27.2)$ \\
\hline Intermediate & $119(62.3)$ \\
\hline Elementary & $16(8.4)$ \\
\hline \multicolumn{2}{|c|}{ Do you consider yourself fluent in writing in English? } \\
\hline Proficient & $55(28.8)$ \\
\hline Intermediate & $117(61.3)$ \\
\hline Elementary & $15(7.9)$ \\
\hline \multicolumn{2}{|c|}{ What is your experience using Internet technologies (e.g., emailing, blogs, wikis)? } \\
\hline Yes & $121(63.4)$ \\
\hline Some & $60(31.4)$ \\
\hline No & $5(2.6)$ \\
\hline \multicolumn{2}{|c|}{$\begin{array}{l}\text { What is your experience using social media and multimedia applications (e.g., graphics, audios, } \\
\text { videos, animations)? }\end{array}$} \\
\hline Yes & $106(55.5)$ \\
\hline Some & $69(36.1)$ \\
\hline No & $11(5.8)$ \\
\hline \multicolumn{2}{|c|}{$\begin{array}{l}\text { How many times per week do you use Blackboard/Internet/social media apps to interact with an } \\
\text { instructor? }\end{array}$} \\
\hline Zero & $6(3.1)$ \\
\hline $1-3$ & $50(26.2)$ \\
\hline $4-6$ & $67(35.1)$ \\
\hline$\geq 7$ & $64(33.5)$ \\
\hline \multicolumn{2}{|c|}{ How many times per week do you use Blackboard/Internet/social apps to interact with classmates? } \\
\hline Zero & $4(2.1)$ \\
\hline $1-3$ & $77(40.3)$ \\
\hline $4-6$ & $52(27.2)$ \\
\hline$\geq 7$ & $53(27.7)$ \\
\hline
\end{tabular}

Note. ICT = information and communication technology; UAE = United Arab Emirates.

\section{Testing the Study Hypotheses Using SEM}

SEM, based on the updated D\&M ISS model, was utilized to evaluate the success of the blended- 
Table 4. Participants' Evaluation of System Quality

\begin{tabular}{|c|c|c|c|c|c|}
\hline Survey item & \% Low & \% Neutral & \% High & Mean & SD \\
\hline The technology used for blended teaching is reliable. & 1.6 & 10.5 & 87.9 & 4.2 & 0.701 \\
\hline $\begin{array}{c}\text { Information (such as online help) provided with the course } \\
\text { website is clear. }\end{array}$ & 4.2 & 20.1 & 75.6 & 4.1 & 0.861 \\
\hline $\begin{array}{c}\text { Information (such as online help) provided with the course } \\
\text { websites is accurate. }\end{array}$ & 4.8 & 19.0 & 76.2 & 4.0 & 0.877 \\
\hline $\begin{array}{c}\text { The educational technology and multimedia used in } \\
\text { this course support interactivity between learners and } \\
\text { instructors by chat, forums, discussions, etc. }\end{array}$ & 8.9 & 17.8 & 73.3 & 4.0 & 0.989 \\
\hline \begin{tabular}{c} 
(n) \\
\hline
\end{tabular}
\end{tabular}

Table 5. Participants' Evaluation of Information Quality

\begin{tabular}{|c|c|c|c|c|c|}
\hline Survey item & \% Low & \% Neutral & \% High & Mean & $S D$ \\
\hline $\begin{array}{c}\text { The course } \\
\text { website provides } \\
\text { the precise } \\
\text { information I } \\
\text { need to complete } \\
\text { the tasks. }\end{array}$ & 1.6 & 12.6 & 85.8 & 4.2 & 0.727 \\
\hline $\begin{array}{c}\text { The information } \\
\text { provided on the } \\
\text { course website is } \\
\text { well organized. }\end{array}$ & 1.6 & 13.1 & 85.3 & 4.3 & 0.740 \\
\hline $\begin{array}{c}\text { The information } \\
\text { provided on the } \\
\text { course website is } \\
\text { up to date. }\end{array}$ & 1.0 & 14.7 & 84.3 & 4.2 & 0.755 \\
\hline $\begin{array}{c}\text { The information } \\
\text { used for blended } \\
\text { teaching is } \\
\text { relevant and } \\
\text { reliable. }\end{array}$ & 1.1 & 13.2 & 85.7 & 4.3 & 0.747 \\
\hline
\end{tabular}

Table 6. Respondents' Evaluation of Service Quality

\begin{tabular}{|c|c|c|c|c|c|}
\hline Survey item & $\%$ Low & $\%$ Neutral & $\%$ High & Mean & $S D$ \\
\hline The instructor uses blended-learning technology appropriately. & 2.1 & 12.0 & 85.9 & 4.4 & 0.798 \\
\hline Feedback on evaluation of tests and other assignments was given in timely manner. & 2.1 & 12.0 & 85.9 & 4.3 & 0.789 \\
\hline Sending feedback messages to other students encourages me to explore and learn. & 2.1 & 13.6 & 84.3 & 4.3 & 0.769 \\
\hline $\begin{array}{l}\text { Interaction and communication were adequately maintained with the course } \\
\text { instructor. }\end{array}$ & 2.1 & 12.8 & 85.1 & 4.3 & 0.780 \\
\hline
\end{tabular}


Table 7. Student (User) Satisfaction

\begin{tabular}{|c|c|c|c|c|c|}
\hline Survey item & \% Low & $\%$ Neutral & $\%$ High & Mean & $S D$ \\
\hline $\begin{array}{l}\text { The technology and multimedia (appropriate audio and video content, animations, } \\
\text { computer simulations, etc.) used for blended learning are user friendly. }\end{array}$ & 1.6 & 9.4 & 89.0 & 4.3 & 0.731 \\
\hline $\begin{array}{l}\text { The directions and navigation required to use the blended-learning technology and } \\
\text { multimedia (including the Blackboard system) are clear. }\end{array}$ & 1.0 & 12.0 & 86.9 & 4.3 & 0.746 \\
\hline I am willing to take another course using blended learning. & 5.2 & 15.7 & 79.1 & 4.2 & 0.948 \\
\hline I would recommend taking a blended-learning course to a friend. & 6.3 & 14.1 & 79.6 & 4.2 & 0.973 \\
\hline
\end{tabular}

Table 8. Participants' Evaluation of System Use

\begin{tabular}{|c|c|c|c|c|c|}
\hline Survey item & $\begin{array}{c}\% \\
\text { Low }\end{array}$ & \% Neutral & \% High & Mean & $S D$ \\
\hline I use the course online materials and multimedia frequently. & 3.1 & 8.9 & 88.0 & 4.3 & 0.793 \\
\hline It is easy to get the technology used in the blended-learning \\
course to do what I want it to do. & 1.6 & 10.5 & 87.9 & 4.3 & 0.743 \\
\hline $\begin{array}{c}\text { I am satisfied with how I am able to apply what I have learned in } \\
\text { this course from both the online and face-to-face parts. }\end{array}$ & 1.6 & 12.2 & 86.2 & 4.3 & 0.792 \\
\hline
\end{tabular}

Table 9. Participants' Evaluation of Net Benefits

\begin{tabular}{|c|c|c|c|c|c|}
\hline Survey item & \% Low & \% Neutral & \% High & Mean & $S D$ \\
\hline $\begin{array}{c}\text { Blended learning improved my learning productivity. } \\
\text { Blended learning enhanced the effectiveness of my study } \\
\text { activities. }\end{array}$ & 2.6 & 15.9 & 81.5 & 4.2 & 0.835 \\
\hline \begin{tabular}{c} 
Blended learning made it easier to study/learn. \\
\hline
\end{tabular} & 4.2 & 18.4 & 79.5 & 4.2 & 0.827 \\
\hline \begin{tabular}{c} 
B \\
\hline
\end{tabular} & & 82.6 & 4.2 & 0.887 \\
\hline
\end{tabular}

learning methodology at UAEU. The framework examines the extent of the relationships between different qualities expected to positively affect the success and NB of blended learning. These included system reliability and ease of use, system precision and organization of information, service quality provided through the use of appropriate technology, and high-quality interactions between involved parties. According to the D\&M ISS model, these qualities are expected to positively influence the SU, SS, and NB of the blended-learning delivery system. As such, the nine hypotheses introduced above were postulated and tested.

Model fit. Model fit was performed with the lavaan version 0.6-6 package in R (Rosseel, 2012). Confirmatory factor analysis results reflected high levels of internal consistency within the constructs, with Cronbach's $\alpha$ values higher than .8, exceeding a recommended level of .7 (see Table 10). Model reliability was further assessed by estimating respective construct reliability, employing the index of composite reliability (CR) to review convergent validity. All CR values exceeded the acceptable base level of .7 (see Table 10).

Similar conclusions were evident when the index of average variance extracted (AVE) was employed to measure convergent validity. AVE measures the level of variance captured by a construct versus the level caused by measurement error. In the current study, a reported value exceeding 0.5 and less than the corresponding CR was declared acceptable.

Maximum shared variance and average shared variance were used to assess the model's discriminant validity. Both measures confirmed the discriminant validity of the fitted SEM model, 
showing values less than the AVE. Moreover, the square root of AVE (boldface in Table 10) provided further support for the discriminant validity of the fitted model; for each construct, the produced value is higher than inter-construct correlations.

Table 10. Assessment of Reliability, Convergent and Divergent Validity, and Constructs' Correlation Matrix

\begin{tabular}{|c|c|c|c|c|c|c|c|c|c|c|c|}
\hline Variable & Cronbach's $\boldsymbol{\alpha}$ & CR & AVE & MSV & ASV & SQ & IQ & SERQ & SS & SU & NB \\
\hline SQ & .86 & .88 & .65 & .58 & .46 & $\mathbf{. 8 0 7}$ & & & & & \\
\hline IQ & .89 & .92 & .75 & .53 & .45 & .676 & $\mathbf{. 8 6 4}$ & & & & \\
\hline SERQ & .82 & .88 & .66 & .62 & .54 & .713 & .726 &. $\mathbf{8 1 0}$ & & & \\
\hline SS & .88 & .92 & .74 & .67 & .59 & .759 & .696 & .785 & $\mathbf{. 8 6 2}$ & & \\
\hline SU & .84 & .91 & .76 & .60 & .51 & .618 & .661 & .748 & .773 &. .874 & \\
\hline NB & .89 & .89 & .73 & .67 & .49 & .628 & .602 & .680 & .817 & .742 & .857 \\
\hline
\end{tabular}

Note. $S Q$ = system quality; $I Q$ = information quality; $S E R Q$ = service quality; $S S$ = student satisfaction; $S U$ = system use; $N B$ = net benefits.

Finally, the model's goodness-of-fit was assessed using five indices: chi-square/degrees of freedom of 2.1, a comparative fit index of 0.924 , Tucker-Lewis index of 0.911 , root-mean-square error of approximation of 0.076 , and root-mean-square residual of 0.053 . The values for all indices were compared with the recommended cut-off level, noted respectively as $\leq 3.0,>0.90,>0.90, \leq$ 0.08 , and $\leq 0.10$.

The results of the fitted SEM model (Table 11 and Figure 2) display the standardized path coefficients and beta coefficients, which determine the effect size of the hypothesized path between the two variables. The larger absolute value of the beta coefficient reflects a stronger effect. Approximately $70 \%$ of the variance in the students' NB from the blended-learning delivery system was explained by two constructs: SU of the blended-learning system, and SS with blended learning. The respective quality dimensions (SQ, IQ, and SERQ) and SS with the UAEU blended-learning delivery system explained $>65 \%$ of the SU.

All hypotheses were supported at different levels of significance (Table 11 and Figure 2), although IQ had an insignificant impact on both $\mathrm{SS}\left(\mathrm{H}_{3}\right)$ and $\mathrm{SU}\left(\mathrm{H}_{4}\right)$. Similar conclusions apply when describing the relationship between SQ and SU $\left(\mathrm{H}_{2}\right)$. SERQ appeared as a strong predictor of SU and SS.

\section{Discussion and Conclusion}

This study evaluated the success of the blended-learning teaching mode utilizing the updated D\&M ISS model. Exploratory analysis revealed favorable student opinions regarding almost all characteristics of blended learning that were hypothesized to positively influence its success. SEM was also utilized to investigate the interrelationships between critical dimensions in blended-learning system success.

Both actual SU and SS had significant positive influences on NB. SS significantly supported the blended-learning SU. SU received indirect support, via student satisfaction, from SQ and SERQ. SERQ provided strong support to both SU and SS. These results were consistent with those of Wu et al. (2010) and Pituch and Lee (2006). Students seemed to appreciate the active learning paradigm wherein learning is a collaborative social activity (Poelmans \& Wessa, 2015).

Several studies have indicated that in a mandatory setting of an IS, irrespective of the quality antecedents, the SQ and IQ would have no or little effect on SU (Iivari, 2005; Jagannathan et al., 2018; Lwoga, 2012; Yakubu \& Dasuki, 2018). This study supports this notion, as no significant link was found between SQ and SU, or between IQ and SU. Even though all items utilized in measuring the information construct received high positive scores, IQ did not achieve the expected levels for SS. Other factors, such as instructor support and peer interaction, might have influenced SS more than IQ. 
Table 11. Standardized Path Coefficients $(\beta)$

\begin{tabular}{|c|c|c|c|}
\hline Path & $\boldsymbol{\beta}$ & $p$ & Remarks \\
\hline $\mathrm{SQ} \rightarrow \mathrm{SS}: \mathrm{H}_{1}$ & .358 & .000 & Supported \\
\hline $\mathrm{SQ} \rightarrow \mathrm{SU}: \mathrm{H}_{2}$ & -.065 & .176 & Not supported \\
\hline $\mathrm{IQ} \rightarrow \mathrm{SS}: \mathrm{H}_{3}$ & .147 & .115 & Not supported \\
\hline $\mathrm{IQ} \rightarrow \mathrm{SU}: \mathrm{H}_{4}$ & .145 & .149 & Not supported \\
\hline $\mathrm{SERQ} \rightarrow \mathrm{SS}: \mathrm{H}_{5}$ & .423 & .000 & Supported \\
\hline $\mathrm{SERQ} \rightarrow \mathrm{SU}: \mathrm{H}_{6}$ & .320 & .019 & Supported \\
\hline $\mathrm{SS} \rightarrow \mathrm{NB}: \mathrm{H}_{7}$ & .604 & .000 & Supported \\
\hline $\mathrm{SU} \rightarrow \mathrm{NB}: \mathrm{H}_{8}$ & .275 & .008 & Supported \\
\hline $\mathrm{SS} \rightarrow \mathrm{SU}: \mathrm{H}_{9}$ & .471 & .001 & Supported \\
\hline
\end{tabular}

Figure 2. Standardized coefficients $(\beta)$ and explained variance $\left(R^{2}\right)$ of the blended-learning success model.

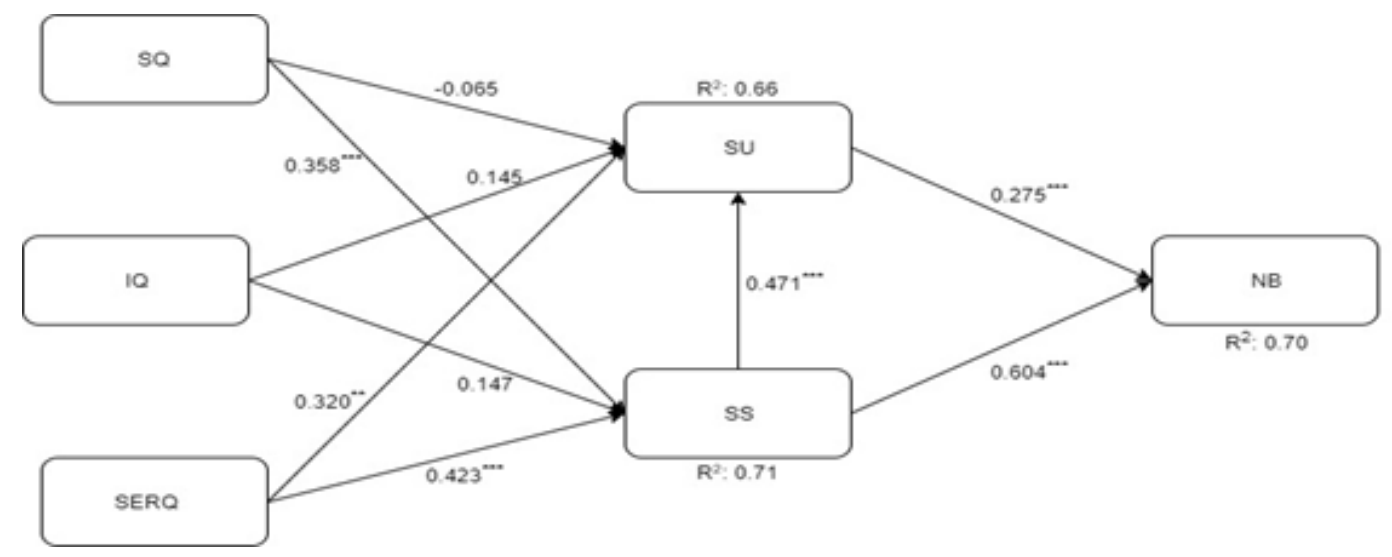

This study is one of few to have evaluated the performance and quality of a blended-learning model in higher education institutions in the Arabian Gulf region. The findings, therefore, provide greater understanding of blended-learning model functioning and the level of SS with blended learning. This will aid curriculum development and assist relevant stakeholders in the process of resource allocation, adoption, and customization of blended learning. The UAEU, for example, could act on the high level of SS reported in this study by developing a strategy to build a community of learners that enjoys flexible access to academic caring and social interaction. The strategy could be centered around the use of the most appropriate technology to enhance the learning process, stimulate social interaction, and dispel feelings of isolation.

\section{Study Limitations}

One limitation of this study is that the courses surveyed were all in the fields of humanities and social sciences. Blended-science courses in such field as physics or mathematics might provide different challenges and could trigger different student feedback. Because of the apparent difficulties of their curricula, they might also trigger the need for more social interaction with instructors. 


\section{ACKNOWLEDGMENT}

This work is supported by the UAEU research office through the SURE Plus 2019 fund. We appreciate the support and assistance of all instructors involved in the design and delivery of the blended courses used in this study. We also thank all students who participated or helped with the blended learning survey, particularly Amira Mohamed and Sanusi Jallow. 


\section{REFERENCES}

Ahmed, W. K., \& Marzouqi, A. H. A. (2015). Using blended learning for self-learning. International Journal of Technology Enhanced Learning, 7(2), 91-98. doi:10.1504/IJTEL.2015.072025

Alkaabi, S. A. R., Albion, P., \& Redmond, P. (2016). Blended learning in the United Arab Emirates: Development of an adaptability model. Asia Pacific Journal of Contemporary Education and Communication Technology, 2(1), 64-86.

AlMurshidi, G. (2017). Opportunities and challenges of mobile learning that university students encounter in the UAE. International Research in Higher Education, 2(4), 18-37. doi:10.5430/irhe.v2n4p18

Atmacasoy, A., \& Aksu, M. (2018). Blended learning at pre-service teacher education in Turkey: A systematic review. Education and Information Technologies, 23(6), 2399-2422. doi:10.1007/s10639-018-9723-5

Bandura, A. (1986). Social foundations of thought and action: A social cognitive theory. Prentice Hall.

Biggs, J. B. (2011). Teaching for quality learning at university: What the student does. McGraw-Hill Education.

Boell, S. K., \& Cecez-Kecmanovic, D. (2015, January). What is an information system? In 2015 48th Hawaii International Conference on System Sciences (pp. 4959-4968). IEEE. doi:10.1109/HICSS.2015.587

Bouilheres, F., McDonald, S., Nkhoma, C., \& Jandug-Montera, L. (2020). Defining student learning experience through blended learning. Education and Information Technologies, 25(4), 3049-3069. doi:10.1007/s10639020-10100-y

Bryan, A., \& Volchenkova, K. N. (2016). Blended learning: Definition, models, implications for higher education. Bulletin of the South Ural State University, 8(2), 24-30. doi:10.14529/ped160204

Chen, C. C., \& Jones, K. T. (2007). Blended learning vs. traditional classroom settings: Assessing effectiveness and student perceptions in an MBA accounting course. Journal of Educators Online, 4(1), 1-15. doi:10.9743/ JEO.2007.1.3

Davis, F. D. (1989). Perceived usefulness, perceived ease of use, and user acceptance of information technology. Management Information Systems Quarterly, 13(3), 319-340. doi:10.2307/249008

DeLone, W. H., \& McLean, E. R. (1992). Information systems success: The quest for the dependent variable. Information Systems Research, 3(1), 60-95. doi:10.1287/isre.3.1.60

DeLone, W. H., \& McLean, E. R. (2003). The DeLone and McLean model of information systems success: A tenyear update. Journal of Management Information Systems, 19(4), 9-30. doi:10.1080/07421222.2003.11045748

Doll, W. J., Deng, X., Raghunathan, T. S., Torkzadeh, G., \& Xia, W. (2004). The meaning and measurement of user satisfaction: A multigroup invariance analysis of the end-user computing satisfaction instrument. Journal of Management Information Systems, 21(1), 227-262. doi:10.1080/07421222.2004.11045789

Graham, C. R. (2006). Blended learning systems: Definition, current trends, and future directions. In C. J. Bonk \& C. R. Graham (Eds.), The handbook of blended learning: Global perspectives, local designs (pp. 3-21). Pfeiffer Publishing.

Hew, K. F., \& Cheung, W. S. (2014). Using blended learning: Evidence-based practices (Vol. 20). Springer.

Holsapple, C. W., \& Lee-Post, A. (2006). Defining, assessing, and promoting e-learning success: An information systems perspective. Decision Sciences Journal of Innovative Education, 4(1), 67-85. doi:10.1111/j.15404609.2006.00102.x

Iivari, J. (2005). An empirical test of the DeLone-McLean model of information system success. ACM SIGMIS Database: The DATABASE for Advances in Information Systems, 36(2), 8-27. doi:10.1145/1066149.1066152

Ives, B., Olson, M. H., \& Baroudi, J. J. (1983). The measurement of user information satisfaction. Communications of the ACM, 26(10), 785-793. doi:10.1145/358413.358430

Jagannathan, V., Balasubramanian, S., \& Natarajan, T. (2018). An extension to the Delone and Mclean information systems success model and validation in the internet banking context. In M. Khosrow-Pour (Ed.), Encyclopedia of Information Science and Technology (4th ed., pp. 49-60). IGI Global. 
Krasnova, T. (2015). A paradigm shift: Blended learning integration in Russian higher education. Procedia: Social and Behavioral Sciences, 166, 399-403. doi:10.1016/j.sbspro.2014.12.543

Lalima, D., \& Dangwal, K. L. (2017). Blended learning: An innovative approach. Universal Journal of Educational Research, 5(1), 129-136. doi:10.13189/ujer.2017.050116

Lee-Post, A. (2009). e-Learning success model: An information systems perspective. Electronic Journal of e-Learning, 7(1), 61-70.

Lwoga, E. (2012). Making learning and Web 2.0 technologies work for higher learning institutions in Africa. Campus-Wide Information Systems, 29(2), 90-107. doi:10.1108/10650741211212359

Oliver, M., \& Trigwell, K. (2005). Can 'blended learning' be redeemed? E-Learning and Digital Media, 2(1), $17-26$

Owston, R., York, D., \& Murtha, S. (2013). Student perceptions and achievement in a university blended learning strategic initiative. The Internet and Higher Education, 18, 38-46. doi:10.1016/j.iheduc.2012.12.003

Park, J. H., \& Choi, H. J. (2009). Factors influencing adult learners' decision to drop out or persist in online learning. Journal of Educational Technology \& Society, 12(4), 207-217.

Patterson, B., \& McFadden, C. (2009). Attrition in online and campus degree programs. Online Journal of Distance Learning Administration, 12(2). https://eric.ed.gov/?id=EJ869274

Pituch, K. A., \& Lee, Y. K. (2006). The influence of system characteristics on e-learning use. Computers \& Education, 47(2), 222-244. doi:10.1016/j.compedu.2004.10.007

Poelmans, S., \& Wessa, P. (2015). A constructivist approach in a blended e-learning environment for statistics. Interactive Learning Environments, 23(3), 385-401. doi:10.1080/10494820.2013.766890

Ramayah, T., Ahmad, N. H., \& Lo, M. C. (2010). The role of quality factors in intention to continue using an e-learning system in Malaysia. Procedia: Social and Behavioral Sciences, 2(2), 5422-5426. doi:10.1016/j. sbspro.2010.03.885

Rosseel, Y. (2012). Lavaan: An R package for structural equation modeling and more. Version 0.5-12 (BETA). Journal of Statistical Software, 48(2), 1-36. doi:10.18637/jss.v048.i02

Rovai, A. P., \& Jordan, H. M. (2004). Blended learning and sense of community: A comparative analysis with traditional and fully online graduate courses. International Review of Research in Open and Distributed Learning, 5(2), 1-13. doi:10.19173/irrodl.v5i2.192

Sharpe, R., Benfield, G., Roberts, G., \& Francis, R. (2006). The undergraduate experience of blended e-learning: A review of UK literature and practice. The Higher Education Academy. https://www.heacademy.ac.uk/system/ files/Sharpe_Benfield_Roberts_Francis_SUMMARY_0.pdf

Staker, H., \& Horn, M. B. (2012). Classifying K-12 blended learning. Innosight Institute.

Szadziewska, A., \& Kujawski, J. (2017). Advantages and disadvantages of the blended-learning method used in the educational process at the faculty of management at the University of Gdansk, in the opinion of undergraduate students. ICERI Proceedings, 3938-3946. doi:10.21125/iceri.2017.1051

Urbach, N., \& Müller, B. (2012). The updated DeLone and McLean model of information systems success. In Y. Dwivedi, M. Wade, \& S. Schneberger (Eds.), Information systems theory. Integrated series in information systems (Vol 28). Springer. doi:10.1007/978-1-4419-6108-2_1

Vonderwell, S. (2003). An examination of asynchronous communication experiences and perspectives of students in an online course: A case study. The Internet and Higher Education, 6(1), 77-90. doi:10.1016/ S1096-7516(02)00164-1

Wentzel, K. R. (2009). Students' relationships with teachers as motivational contexts. In K. R. Wentzel \& A. Wigfield (Eds.), Handbook of motivation at school (pp. 301-322). Taylor \& Francis. doi:10.4324/9780203879498

Wu, J. H., Tennyson, R. D., \& Hsia, T. L. (2010). A study of student satisfaction in a blended e-learning system environment. Computers \& Education, 55(1), 155-164. doi:10.1016/j.compedu.2009.12.012 
Yakubu, M. N., \& Dasuki, S. (2018). Assessing eLearning systems success in Nigeria: An application of the DeLone and McLean information systems success model. Journal of Information Technology Education, 17, 183-203. doi:10.28945/4077

Ibrahim Abdalla Alfaki is Associate Professor of Statistics - Department of Analytics at the College of Business \& Economics of the University of the United Arab Emirates (UAEU). His research interests span several areas in applied statistics, knowledge economy and data analytics, with extended research in the assessment of educational learning outcomes and modes of learning delivery. 